\title{
Komparasi Algoritma Naive Bayes dan Decision Tree Untuk Memprediksi Lama Studi Mahasiswa
}

\author{
Indera Cahyo Wibowo ${ }^{1, *}$, Abd Charis Fauzan², Marshella Dwi Putri Yustiana ${ }^{3}$, Fiqih Ainul Qhabib ${ }^{4}$ \\ Program Studi Ilmu Komputer, Universitas Nahdlatul Ulama Blitar, Indonesia \\ 1 inderacw1902@gmail.com; ${ }^{2}$ abdcharis@ unublitar.ac.id; ${ }^{3}$ marshelladwi17@gmail.com; ${ }^{4}$ fiqihainul61@gmail.com \\ * corresponding author
}

ARTIKEL INFO

Article history

Diterima: 3 Oktober 2019

Direvisi: 11 November 2019

Diterbitkan: 30 Desember 2019

Keywords

Naïve bayes

Decision tree

Komparasi algoritma

\section{ABSTRAK}

Penelitian ini bertujuan memprediksi lama studi mahasiswa lulus tepat waktu atau terlambat lulus. Data yang digunakan yaitu: gender, status mahasiswa, nilai, dan beasiswa dari semester awal sampai semester akhir di tahun ajaran 2018 - 2019. Penelitian ini menggunakan 2 metode, untuk metode yang pertama adalah Naïve Bayes dan yang kedua adalah Decision Tree. Gunakan semua data yang telah diperoleh dan hitung dengan kedua metode sampai mendapatkan hasil akhir dan akurasinya lalu komparasikan keduanya. Hasil pengkomparasian dari data dan menggunakan dua metode perhitungan keakurasiannya yaitu $30 \%$ untuk Naïve bayes, dan 55\% untuk metode Decision Tree. Dari komparasi menggunakan dua metode dapat diambil kesimpulan bahwa metode Decision Tree memiliki persentase keakuratan yang lebih tinggi dibandingkan Naïve Bayes sehingga dapat dikatakan metode Decision Tree lebih akurat dan lebih detail daripada Naïve Bayes.

\section{PENDAHULUAN}

Salah satu faktor yang menentukan kualitas perguruan tinggi adalah kemampuan mahasiswa untuk menyelesaikan masa studi secara tepat waktu karena kegagalan mahasiswa dalam menyelesaikan program sarjana (S1) akan menyebabkan masalahmasalah baru yang berkaitan dengan masa depan mahasiswa tersebut. Pada dasarnya mahasiswa diberi waktu untuk menyelesaikan program sarjana (S1) dalam kurun waktu 8 semester agar studi selesai tepat waktu. Oleh karenanya, setiap perguruan tinggi pun dirasa perlu untuk melakukan prediksi untuk memperoleh informasi yang tepat dan akurat mengenai mahasiswa yang mampu menyelesaikan masa studinya dengan tepat waktu 8 semester sehingga perguruan tinggi dapat mencegah kegagalan kegiatan akademik mahasiswa secara dini [1]. Pada penelitian terdahulu, algoritma K-Nearest Neighbor btelah digunakan untuk klarifikasi data [2]. Pada penelitian ini akan dirancang perhitungan lama studi mahasiswa dengan menggunakan metode algoritma naive bayes dan decision tree. Naive bayes dan decision tree merupakan metode pengklasifikasi yang terkenal dengan tingkat keakuratan yang baik [3]. Banyak peneliti yang melakukan penelitian dengan menggunakan klarifikasi dua metode tersebut [4]. Kebanyakan dari peneliti mempunyai dasar pada ilmu komputer dan informatika komputer sehingga pada pembahasan ini lebih ditekankan pada hasil pemrograman, keakuratan, dan yang terpenting adalah pada probabilitasnya [5]. Berdasarkan masalah yang diuraikan maka penelitian ini membahas komparasi algoritma naive bayes dan decision tree. Tujuan diadakannya komparasi ini adalah diharapkan akan diketahui metode yang mendapatkan akurasi lebih besar. Berikutnya, metode yang terbaik diantara keduanya dipakai dalam menentukan prediksi kelulusan mahasiswa, yaitu antara tepat waktu atau terlambat. 


\section{METODE}

Pengumpulan data beserta tahapan untuk komparasi algoritma pada Gambar 1. Gambar 1 menunjukkan urutan dalam pengerjaan komparasi Naive Bayes dan Decision Tree untuk mendapatkan tingkat akurasi yang paling besar diantara dua metode.

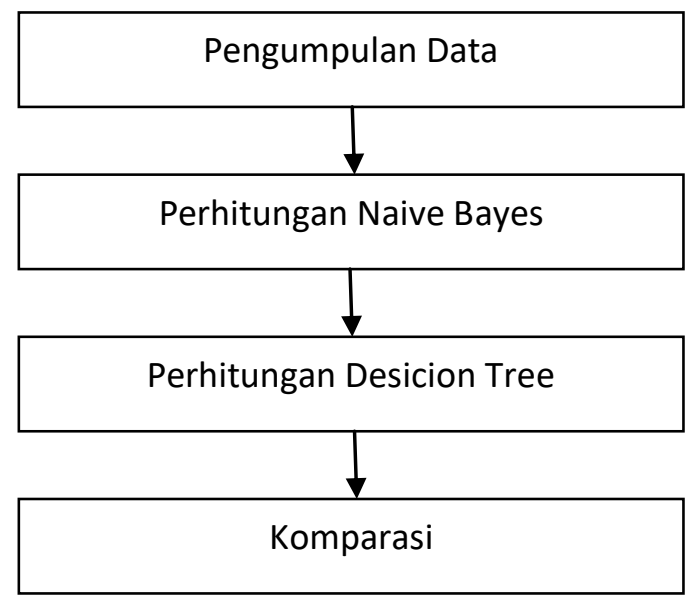

Gambar 1. Urutan Pengerjaan Komparasi Naive Bayes dan Decision

\section{Pengumpulan Data}

Data studi mahasiswa didapat dari Universitas Nahdlatul Ulama Blitar dari semester awal sampai semester akhir pada tahun ajaran 2018 - 2019, pada data tersebut terdapat atribut asli yaitu: Gender, Status Mahasiswa, Nilai, dan Beasiswa seperti pada Tabel 1.

\section{Perhitungan Naive Bayes}

Naive bayes merupakan salah satu metode pembelajaran mesin yang memanfaatkan perhitungan probabilitas dan statistik yang dikemukakan oleh ilmuan Inggris Thomas Bayes, yaitu memprediksi probabilitas di masa depan berdasarkan pengalaman di masa sebelumnya [6]. Dalam metode ini perhitungan ditunjukkan melalui Persamaan 1 :

$$
P(H \mid X)=\frac{P(X \mid H)}{P(X)} \cdot P(H)
$$

Keterangan

$\mathrm{X} \quad$ : Data dengan class yang belum diketahui

$\mathrm{H} \quad$ : Hipotesis data merupakan suatu class spesifik

$\mathrm{P}(\mathrm{H} \mid \mathrm{X}) \quad$ : Probabilitas hipotesis $\mathrm{H}$ berdasar kondisi X (posteriori probabilitas)

$\mathrm{P}(\mathrm{H})$ : Probabilitas hipotesis $\mathrm{H}$ (prior probabilitas)

$\mathrm{P}(\mathrm{X} \mid \mathrm{H})$ : Probabilitas $\mathrm{X}$ berdasarkan kondisi pada hipotesis $\mathrm{H}$

$\mathrm{P}(\mathrm{X})$ : Probabilitas X [7]

\section{Perhitungan Decision Tree}

Konsep Decision Tree atau Pohon keputusan adalah mengubah data menjadi aturan aturan keputusan. Manfaat utama dari penggunaan decision tree adalah kemampuannya untuk mem-break down proses pengambilan keputusan yang kompleks menjadi simple, sehingga pengambilan keputusan akan lebih memudahkan solusi dari sebuah permasalahan [8]. Decision Tree adalah salah satu metode klasifikasi yang paling populer karena mudah diinterprestasikan oleh manusia [9]. Decision Tree digunakan untuk pengenalan pola dan termasuk dalam pengenalan pola secara statistic [10]. Decision Tree menggunakan 2 
perhitungan yang pertama adalah perhitungan Gain pada Persamaan 2 dan perhitungan Entropy pada Persamaan 3 [5].

Perhitungan Gain

$$
\text { Gain }(S, A)=\operatorname{Entropy}(S)-\sum_{i=1}^{n} \quad * \operatorname{Entropy}(S i)
$$

Keterangan:

$$
\begin{array}{ll}
\mathrm{S} & \text { : himpunan } \\
\mathrm{A} & \text { :atribut } \\
\mathrm{n} & \text { : jumlah partisi atribut } \mathrm{A} \\
|\mathrm{Si}| & \text { : jumlah kasus pada partikel ke-i } \\
|\mathrm{S}| & \text { : jumlah kasusdalam } \mathrm{S}
\end{array}
$$

Menghitung Nilai Entropy

$$
\text { Entropy }(\mathrm{S})=\sum_{i=1}^{\mathrm{n}}-p i * \log _{2} p i
$$

Keterangan :

$\begin{array}{ll}\text { S } & \text { : himpunan kasus } \\ \text { A } & \text { : fitur } \\ \text { n } & \text { : jumlah partisi S } \\ \text { pi } & \text { : Proporsi dari Si terhadap S [5] }\end{array}$

\section{PEMBAHASAN}

Untuk menentukan masa studi mahasiswa, pada penelitian ini akan dilakukan analisis menggunakan Algoritma Decision Tree dan juga Naive bayes untuk mengetahui mana yang lebih baik diantara keduanya, sehingga perlu dilakukan proses analisa data terlebih dahulu sebelum data yang digunakan tersebut di komparasikan. Dalam menganalisa data mahasiswa alumni tersebut, maka ada atribut yang digunakan untuk menentukan masa studi mahasiswa yaitu: Gender, Status Mahasiswa, Nilai dan juga Status Beasiswa. Beberapa dari empat atribut tersebut akan dijadikan atribut prediktor atau atribut input untuk menghasilkan atribut target, di mana atribut target tersebut menjadi class output untuk menentukan masa studi yaitu dibedakan menjadi 2 class (Tepat Waktu dan Terlambat). Berikut ini adalah keterangan data mahasiswa yang akan digunakan dalam menentukan masa studi mahasiswa terlihat pada Tabel 1.

Tabel 1. Keterangan Data Mahasiswa

\begin{tabular}{|l|l|l|}
\hline NO & ATRIBUT & KETERANGAN \\
\hline 1 & Gender & Menentukan jenis kelamin dari mahasiswa (pria/wanita) \\
\hline 2 & Status Mahasiswa & Menentukan status mahasiswa (mahasiswa/bekerja) \\
\hline 3 & Nilai & Menentukan nilai mahasiswa (A, B / C) \\
\hline 4 & Beasiswa & Menentukan status beasiswa (YA / TIDAK) \\
\hline
\end{tabular}


Berdasarkan data tersebut kemudian dilakukan pemilihan atribut dan sebagian dari data dalam atribut yang ada akan ditransformasikan untuk memudahkan proses mining dalam menentukan masa studi. Adapun data yang digunakan untuk menentukan masa studi mahasiswa ditunjukkan pada Tabel 2, yakni 100 data yang diambil secara acak. Data pada Tabel 3 didapat dari data mahasiswa Universitas Nahdlatul Ulama Blitar pada tahun akademik 2018-2019.

Tabel 2. Sample Data Mahasiswa

\begin{tabular}{|c|c|c|c|c|c|c|}
\hline NO & GENDER & $\begin{array}{l}\text { STATUS } \\
\text { MAHASISWA }\end{array}$ & NILAI & BEASISWA & LAMA STUDI & PREDIKSI \\
\hline 1 & PRIA & MAHASISWA & A & YA & TEPAT WAKTU & TERLAMBAT \\
\hline 2 & WANITA & BEKERJA & B & YA & TEPAT WAKTU & TEPAT WAKTU \\
\hline 3 & PRIA & MAHASISWA & $\mathrm{C}$ & TIDAK & TERLAMBAT & TEPAT WAKTU \\
\hline 4 & PRIA & MAHASISWA & A & YA & TEPAT WAKTU & TEPAT WAKTU \\
\hline 5 & WANITA & MAHASISWA & A & YA & TEPAT WAKTU & TEPAT WAKTU \\
\hline 6 & PRIA & BEKERJA & B & YA & TERLAMBAT & TEPAT WAKTU \\
\hline 7 & WANITA & MAHASISWA & B & YA & TEPAT WAKTU & TEPAT WAKTU \\
\hline 8 & PRIA & BEKERJA & $\mathrm{C}$ & TIDAK & TERLAMBAT & TEPAT WAKTU \\
\hline 9 & PRIA & BEKERJA & $\mathrm{C}$ & TIDAK & TERLAMBAT & TEPAT WAKTU \\
\hline 10 & WANITA & MAHASISWA & A & YA & TEPAT WAKTU & TEPAT WAKTU \\
\hline 11 & WANITA & BEKERJA & A & YA & TEPAT WAKTU & TEPAT WAKTU \\
\hline 12 & WANITA & BEKERJA & B & YA & TERLAMBAT & TEPAT WAKTU \\
\hline 13 & WANITA & MAHASISWA & A & YA & TEPAT WAKTU & TEPAT WAKTU \\
\hline 14 & PRIA & BEKERJA & B & YA & TEPAT WAKTU & TEPAT WAKTU \\
\hline 15 & PRIA & MAHASISWA & $\mathrm{C}$ & TIDAK & TERLAMBAT & TEPAT WAKTU \\
\hline 16 & WANITA & MAHASISWA & A & YA & TEPAT WAKTU & TEPAT WAKTU \\
\hline 17 & WANITA & MAHASISWA & $\mathrm{C}$ & TIDAK & TERLAMBAT & TEPAT WAKTU \\
\hline 18 & PRIA & BEKERJA & B & YA & TEPAT WAKTU & TERLAMBAT \\
\hline 19 & PRIA & BEKERJA & $\mathrm{C}$ & TIDAK & TERLAMBAT & TEPAT WAKTU \\
\hline 20 & PRIA & BEKERJA & B & YA & TERLAMBAT & TEPAT WAKTU \\
\hline 21 & PRIA & MAHASISWA & A & YA & TEPAT WAKTU & TEPAT WAKTU \\
\hline 22 & WANITA & MAHASISWA & A & YA & TEPAT WAKTU & TEPAT WAKTU \\
\hline 23 & WANITA & MAHASISWA & B & YA & TEPAT WAKTU & TEPAT WAKTU \\
\hline 24 & PRIA & MAHASISWA & $\mathrm{C}$ & TIDAK & TERLAMBAT & TEPAT WAKTU \\
\hline 25 & PRIA & BEKERJA & $\mathrm{C}$ & TIDAK & TERLAMBAT & TEPAT WAKTU \\
\hline 26 & WANITA & MAHASISWA & B & YA & TERLAMBAT & TEPAT WAKTU \\
\hline 27 & WANITA & BEKERJA & A & YA & TEPAT WAKTU & TEPAT WAKTU \\
\hline 28 & WANITA & BEKERJA & A & YA & TEPAT WAKTU & TEPAT WAKTU \\
\hline 29 & WANITA & MAHASISWA & B & YA & TERLAMBAT & TEPAT WAKTU \\
\hline 30 & WANITA & BEKERJA & B & YA & TEPAT WAKTU & TEPAT WAKTU \\
\hline 31 & PRIA & BEKERJA & $\mathrm{C}$ & TIDAK & TERLAMBAT & TEPAT WAKTU \\
\hline 32 & PRIA & MAHASISWA & $\mathrm{C}$ & TIDAK & TERLAMBAT & TEPAT WAKTU \\
\hline 33 & WANITA & BEKERJA & $\mathrm{C}$ & TIDAK & TERLAMBAT & TEPAT WAKTU \\
\hline 34 & PRIA & MAHASISWA & A & YA & TEPAT WAKTU & TERLAMBAT \\
\hline 35 & WANITA & BEKERJA & B & YA & TEPAT WAKTU & TEPAT WAKTU \\
\hline 36 & PRIA & BEKERJA & B & YA & TERLAMBAT & TEPAT WAKTU \\
\hline 37 & WANITA & BEKERJA & B & YA & TEPAT WAKTU & TEPAT WAKTU \\
\hline 38 & PRIA & MAHASISWA & B & YA & TEPAT WAKTU & TEPAT WAKTU \\
\hline 39 & PRIA & MAHASISWA & A & YA & TEPAT WAKTU & TEPAT WAKTU \\
\hline 40 & PRIA & MAHASISWA & A & YA & TEPAT WAKTU & TEPAT WAKTU \\
\hline 41 & PRIA & MAHASISWA & A & YA & TEPAT WAKTU & TEPAT WAKTU \\
\hline 42 & WANITA & BEKERJA & B & YA & TERLAMBAT & TEPAT WAKTU \\
\hline 43 & WANITA & MAHASISWA & B & YA & TERLAMBAT & TEPAT WAKTU \\
\hline 44 & PRIA & BEKERJA & B & YA & TEPAT WAKTU & TEPAT WAKTU \\
\hline 45 & PRIA & BEKERJA & A & YA & TEPAT WAKTU & TEPAT WAKTU \\
\hline
\end{tabular}




\begin{tabular}{|c|c|c|c|c|c|c|}
\hline 46 & WANITA & MAHASISWA & $\mathrm{C}$ & TIDAK & TERLAMBAT & TEPAT WAKTU \\
\hline 47 & WANITA & BEKERJA & $\mathrm{C}$ & TIDAK & TERLAMBAT & TERLAMBAT \\
\hline 48 & PRIA & BEKERJA & $\mathrm{C}$ & TIDAK & TERLAMBAT & TERLAMBAT \\
\hline 49 & PRIA & MAHASISWA & A & YA & TEPAT WAKTU & TEPAT WAKTU \\
\hline 50 & PRIA & BEKERJA & A & YA & TEPAT WAKTU & TEPAT WAKTU \\
\hline 51 & PRIA & BEKERJA & B & YA & TERLAMBAT & TEPAT WAKTU \\
\hline 52 & WANITA & MAHASISWA & B & YA & TEPAT WAKTU & TEPAT WAKTU \\
\hline 53 & WANITA & BEKERJA & A & YA & TEPAT WAKTU & TEPAT WAKTU \\
\hline 54 & PRIA & MAHASISWA & A & YA & TEPAT WAKTU & TEPAT WAKTU \\
\hline 55 & WANITA & BEKERJA & A & YA & TEPAT WAKTU & TEPAT WAKTU \\
\hline 56 & PRIA & BEKERJA & $\mathrm{C}$ & TIDAK & TERLAMBAT & TEPAT WAKTU \\
\hline 57 & WANITA & BEKERJA & B & YA & TERLAMBAT & TEPAT WAKTU \\
\hline 58 & WANITA & MAHASISWA & $\mathrm{C}$ & TIDAK & TERLAMBAT & TEPAT WAKTU \\
\hline 59 & WANITA & MAHASISWA & B & YA & TEPAT WAKTU & TERLAMBAT \\
\hline 60 & PRIA & BEKERJA & A & YA & TEPAT WAKTU & TEPAT WAKTU \\
\hline 61 & PRIA & BEKERJA & B & YA & TEPAT WAKTU & TEPAT WAKTU \\
\hline 62 & PRIA & BEKERJA & A & YA & TEPAT WAKTU & TEPAT WAKTU \\
\hline 63 & WANITA & MAHASISWA & $\mathrm{C}$ & TIDAK & TERLAMBAT & TEPAT WAKTU \\
\hline 64 & WANITA & MAHASISWA & $\mathrm{C}$ & TIDAK & TERLAMBAT & TERLAMBAT \\
\hline 65 & PRIA & MAHASISWA & $\mathrm{C}$ & TIDAK & TERLAMBAT & TERLAMBAT \\
\hline 66 & WANITA & BEKERJA & B & YA & TEPAT WAKTU & TEPAT WAKTU \\
\hline 67 & PRIA & MAHASISWA & B & $\mathrm{YA}$ & TERLAMBAT & TEPAT WAKTU \\
\hline 68 & WANITA & BEKERJA & B & YA & TEPAT WAKTU & TEPAT WAKTU \\
\hline 69 & PRIA & MAHASISWA & A & YA & TEPAT WAKTU & TEPAT WAKTU \\
\hline 70 & PRIA & BEKERJA & $\mathrm{C}$ & TIDAK & TERLAMBAT & TEPAT WAKTU \\
\hline 71 & PRIA & MAHASISWA & $\mathrm{C}$ & TIDAK & TERLAMBAT & TEPAT WAKTU \\
\hline 72 & PRIA & MAHASISWA & $\mathrm{B}$ & YA & TERLAMBAT & TEPAT WAKTU \\
\hline 73 & WANITA & MAHASISWA & B & YA & TEPAT WAKTU & TEPAT WAKTU \\
\hline 74 & WANITA & BEKERJA & $\mathrm{C}$ & TIDAK & TERLAMBAT & TEPAT WAKTU \\
\hline 75 & WANITA & MAHASISWA & A & YA & TEPAT WAKTU & TERLAMBAT \\
\hline 76 & PRIA & BEKERJA & A & YA & TEPAT WAKTU & TEPAT WAKTU \\
\hline 77 & WANITA & MAHASISWA & $\mathrm{C}$ & TIDAK & TERLAMBAT & TEPAT WAKTU \\
\hline 78 & PRIA & BEKERJA & $\mathrm{C}$ & TIDAK & TERLAMBAT & TERLAMBAT \\
\hline 79 & WANITA & MAHASISWA & B & YA & TEPAT WAKTU & TEPAT WAKTU \\
\hline 80 & PRIA & BEKERJA & A & YA & TEPAT WAKTU & TEPAT WAKTU \\
\hline 81 & PRIA & MAHASISWA & B & YA & TEPAT WAKTU & TEPAT WAKTU \\
\hline 82 & PRIA & BEKERJA & $\mathrm{C}$ & TIDAK & TERLAMBAT & TEPAT WAKTU \\
\hline 83 & WANITA & MAHASISWA & $\mathrm{C}$ & TIDAK & TERLAMBAT & TEPAT WAKTU \\
\hline 84 & WANITA & MAHASISWA & $\mathrm{C}$ & TIDAK & TERLAMBAT & TERLAMBAT \\
\hline 85 & PRIA & MAHASISWA & $\mathrm{A}$ & YA & TEPAT WAKTU & TERLAMBAT \\
\hline 86 & WANITA & BEKERJA & A & YA & TEPAT WAKTU & TEPAT WAKTU \\
\hline 87 & PRIA & MAHASISWA & A & $\mathrm{YA}$ & TEPAT WAKTU & TEPAT WAKTU \\
\hline 88 & PRIA & BEKERJA & B & YA & TERLAMBAT & TEPAT WAKTU \\
\hline 89 & WANITA & MAHASISWA & $\mathrm{B}$ & YA & TEPAT WAKTU & TEPAT WAKTU \\
\hline 90 & WANITA & BEKERJA & B & YA & TERLAMBAT & TEPAT WAKTU \\
\hline 91 & PRIA & MAHASISWA & A & YA & TEPAT WAKTU & TEPAT WAKTU \\
\hline 92 & PRIA & MAHASISWA & $\mathrm{C}$ & TIDAK & TERLAMBAT & TEPAT WAKTU \\
\hline 93 & WANITA & BEKERJA & B & YA & TEPAT WAKTU & TEPAT WAKTU \\
\hline 94 & PRIA & MAHASISWA & $\mathrm{C}$ & TIDAK & TERLAMBAT & TEPAT WAKTU \\
\hline 95 & WANITA & MAHASISWA & B & YA & TEPAT WAKTU & TEPAT WAKTU \\
\hline 96 & PRIA & MAHASISWA & $\mathrm{C}$ & TIDAK & TERLAMBAT & TEPAT WAKTU \\
\hline 97 & PRIA & MAHASISWA & B & YA & TERLAMBAT & TEPAT WAKTU \\
\hline 98 & WANITA & BEKERJA & A & YA & TEPAT WAKTU & TEPAT WAKTU \\
\hline 99 & PRIA & BEKERJA & A & YA & TEPAT WAKTU & TEPAT WAKTU \\
\hline
\end{tabular}




\begin{tabular}{|l|l|l|l|l|l|l|}
\hline 100 & WANITA & MAHASISWA & A & YA & TEPAT WAKTU & TEPAT WAKTU \\
\hline
\end{tabular}

\section{Perhitungan Menggunakan Metode Naive Bayes}

Pada kasus ini, data training bisa dilihat pada Tabel 3, data training sendiri terdiri dari 4 atribut yaitu, Gender, Status Mahasiswa, Nilai, dan Status Beasiswa dan juga terdapat 2 kelas yaitu Tepat Waktu dan Terlambat. Selanjutnya, dilakukan proses untuk menghitung jumlah kelas/label "P(H)" dihitung untuk probabilitas masing-masing kelas:

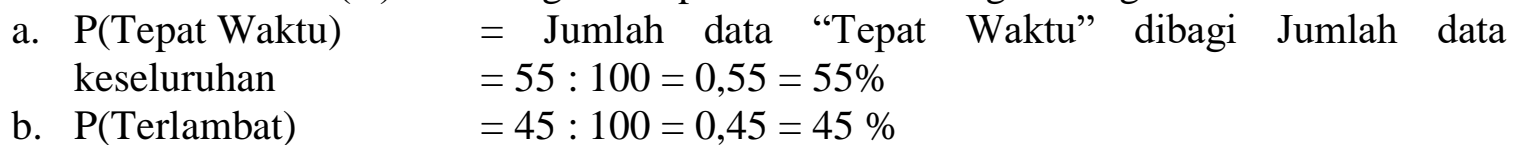

Tabel 2. Probabilitas Kelas Tepat waktu \& Terlambat

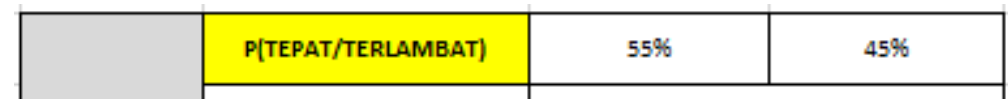

Tabel 4 menunjukkan bahwa probabilitas Kelas Tepat sebesar 55\% dan Kelas Terlambat sebesar $45 \%$. Proses berikutnya adalah menghitung jumlah kasus per kelas " $\mathrm{P}(\mathrm{X} \mid \mathrm{H})$ " , Berdasarkan Tabel 5 dihitung probabilitas per kelas pada tiap atributnya. Tabel 6 adalah proses mengalikan semua variabel kelas dengan hasil probabilitas yang telah didapatkan.

Tabel 5. Probabilitas Masing-Masing Atribut

\begin{tabular}{|c|c|c|c|}
\hline \multirow{18}{*}{ 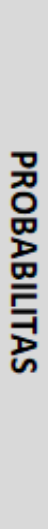 } & P(TEPAT/TERLAMBAT) & $55 \%$ & $45 \%$ \\
\hline & P(GENDER) & TEPAT WAKTU & TERLAMBAT \\
\hline & PRIA & $47 \%$ & $60 \%$ \\
\hline & WANITA & $53 \%$ & $40 \%$ \\
\hline & JUMLAH & $100 \%$ & $100 \%$ \\
\hline & P(STATUS MAHASISWA) & TEPAT & TERLAMBAT \\
\hline & MAHASISWA & $55 \%$ & $51 \%$ \\
\hline & BEKERJA & $45 \%$ & $49 \%$ \\
\hline & JUMLAH & $100 \%$ & $100 \%$ \\
\hline & $P$ (NILAI) & TEPAT & TERLAMBAT \\
\hline & $\mathbf{A}$ & $62 \%$ & $0 \%$ \\
\hline & $B$ & $38 \%$ & $33 \%$ \\
\hline & c & $0 \%$ & $67 \%$ \\
\hline & JUMLAH & $100 \%$ & $100 \%$ \\
\hline & P(BEASISWA $)$ & TEPAT & TERLAMBAT \\
\hline & YA & $100 \%$ & $33 \%$ \\
\hline & TIDAK & $0 \%$ & $67 \%$ \\
\hline & JUMLAH & $100 \%$ & $100 \%$ \\
\hline
\end{tabular}

Tabel 6. Hasil Perhitungan Kelas Tepat Waktu \& Terlambat

\begin{tabular}{c|c|c|c|c|c|c|c} 
NO & GENDER & $\begin{array}{c}\text { STATUS } \\
\text { MLAHASISWA }\end{array}$ & NILAI & BEASISWA & LAMA STUDI & TEPAT WAKTU & TERL.AMIBAT \\
\hline 1 & PRIA & MAHASISWA & A & YA & TEPAT WAKTU & $8,77 \%$ & $0,00 \%$ \\
\hline 2 & WANITA & BEKERIA & B & YA & TEPAT WAKTU & $5,03 \%$ & $0,98 \%$ \\
\hline 4 & PRIA & MAHASISWA & A & YA & TEPAT WAKTU & $8,77 \%$ & $0,00 \%$ \\
\hline 5 & WANITA & MAHASISWA & A & YA & TEPAT WAKTU & $9,78 \%$ & $0,00 \%$ \\
\hline 7 & WANITA & MAHASISWA & B & YA & TEPAT WAKTU & $6,04 \%$ & $1,02 \%$ \\
\hline 10 & WANITA & MAHASISWA & A & YA & TEPAT WAKTU & $9,78 \%$ & $0,00 \%$ \\
\hline 11 & WANITA & BEKERIA & A & YA & TEPAT WAKTU & $8,15 \%$ & $0,00 \%$ \\
\hline 13 & WANITA & MAHASISWA & A & YA & TEPAT WAKTU & $9,78 \%$ & $0,00 \%$ \\
\hline 14 & PRIA & BEKERA & B & YA & TEPAT WAKTU & $4,51 \%$ & $1,47 \%$ \\
\hline 16 & WANITA & MAHASISWA & A & YA & TEPAT WAKTU & $9,76 \%$ & $0,00 \%$ \\
\hline
\end{tabular}

Kemudian, dibandingkan hasil per kelas yang telah didapatkan untuk mendapatkan prediksinya. Berdasarkan Tabel 7 bisa diketahui hasil dari prediksi yang didapatkan dari perbandingan kelas Tepat Waktu dan Terlambat. 
Tabel 7. Perbandingan Kelas Tepat Waktu \& Terlambat

\begin{tabular}{|c|c|c|}
\hline TEPAT WAKTU & TERLAMBAAT & PREDIKSI \\
\hline $8,77 \%$ & $0,00 \%$ & TEPAT WAKTU \\
\hline $5,03 \%$ & $0,98 \%$ & TEPAT WAKTU \\
\hline $8,77 \%$ & $0,00 \%$ & TEPAT WAKTU \\
\hline $9,78 \%$ & $0,00 \%$ & TEPAT WAKTU \\
\hline $6,04 \%$ & $1,02 \%$ & TEPAT WAKTU \\
\hline $9,78 \%$ & $0,00 \%$ & TEPAT WAKTU \\
\hline $8,15 \%$ & $0,00 \%$ & TEPAT WAKTU \\
\hline $9,78 \%$ & $0,00 \%$ & TEPAT WAKTU \\
\hline $4,51 \%$ & $1,47 \%$ & TEPAT WAKTU \\
\hline
\end{tabular}

\section{Perhitungan Menggunakan Metode Decision Tree}

Berdasarkan Tabel 2, maka dilakukan proses perhitungan entropy(1) dan gain(2) untuk menentukan akar (root) dari pohon keputusan dalam membantu menentukan masa studi mahasiswa. Hasil dari perhitungan entropy dan gain pada Node 1 dapat ditunjukkan pada Tabel 8.

\begin{tabular}{|c|c|c|c|c|c|c|c|}
\hline Node & Atribur & Kelas & Jumlah [5] & TEPAT WAKTU [5i] & Teriambat [5i] & Entrophy & Gain \\
\hline \multirow[t]{14}{*}{1} & Total & & 100 & 55 & 45 & 0,99277445 & \\
\hline & Gender & & & & & & 0,0116548 \\
\hline & & Pria & 53 & 26 & 27 & 0,99974319 & \\
\hline & & Wanita & 47 & 29 & 18 & 0,96011866 & \\
\hline & Status Mahasiswa & & & & & & 0,0008453 \\
\hline & & Mahasiswa & 53 & 30 & 23 & 0,98738002 & \\
\hline & & Bekerja & 47 & 25 & 22 & 0,99705906 & \\
\hline & Nilai & & & & & & 0,6400217 \\
\hline & & A & 34 & 34 & 0 & 0 & \\
\hline & & $\mathrm{B}$ & 36 & 21 & 15 & 0,97986876 & \\
\hline & & $\mathrm{C}$ & 30 & 0 & 30 & 0 & \\
\hline & Beasiswa & & & & & & 0,4680578 \\
\hline & & YA & 70 & 55 & 15 & 0,74959526 & \\
\hline & & Tidak & 30 & 0 & 30 & 0 & \\
\hline
\end{tabular}

Tabel 8. Hasil Perhitungan Gain dan Entrophy pada Node 1

Dari hasil Tabel 8, dapat diketahui bahwa atribut dengan gain tertinggi adalah "Nilai", yaitu 0,6400217. Dengan demikian atribut "Nilai" dapat dijadikan node akar. Dari hasil perhitungan nilai entropy dan gain pada node 1, maka dapat digambarkan decision tree sementara seperti terlihat pada Gambar 1.

Tabel 9. Hasil Perhitungan Gain dan Entrophy pada Node 1.2

\begin{tabular}{|c|c|c|c|c|c|c|c|}
\hline Node & Atribur & Kelas & Jumlah̆ (S) & TEPAT WAKTU (Si) & Terlambat (Si) & Entrophy & Gain \\
\hline \multirow[t]{10}{*}{11} & Total & & 36 & 21 & 15 & 0,979869 & \\
\hline & Gender & & & & & & 0,045262 \\
\hline & & Pria & 14 & 6 & 8 & 0,985228 & \\
\hline & & Wanita & 22 & 15 & 7 & 0,902393 & \\
\hline & Status Mahasiswa & & & & & & 0,004135 \\
\hline & & Mahasiswa & 20 & 11 & 9 & 0,992774 & \\
\hline & & Bekerja & 16 & 10 & 6 & 0,954434 & \\
\hline & Beasiswa & & & & & & 0 \\
\hline & & YA & 36 & 21 & 15 & 0,979869 & \\
\hline & & Tidak & 0 & 0 & 0 & 0 & \\
\hline
\end{tabular}




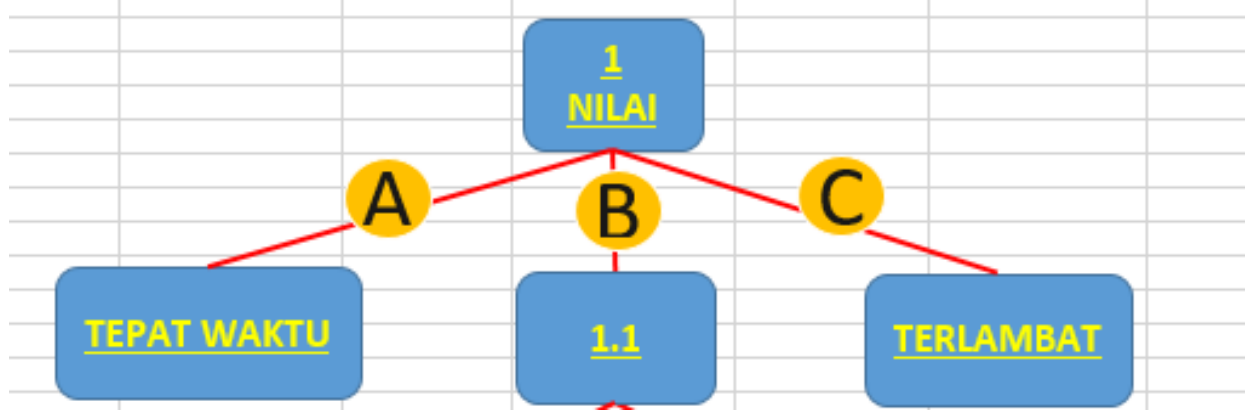

Gambar 1. Decision Tree Node 1

Ada 3 nilai atribut "Nilai" yaitu "A", "B", dan "C" dimana didapatkan nilai nilai "A" adalah "Tepat Waktu" nilai "C" adalah terlambat dan nilai "B" masih belum bisa diputuskan, oleh karena itu nilai B dihitung entrophy dan gain lebih lanjut, terlihat pada Tabel 9. Pada hasil Tabel 9 dapat diketahui bahwa atribut dengan gain tertinggi adalah "Gender" yaitu 0,045262. Dengan demikian "Gender" dapat menjadi node cabang dari "Nilai" yang bernilai "B". Dari Hasil perhitungan nilai entropy dan gain pada node 1.1, maka dapat digambarkan decision tree sementara seperti yang terlihat pada Gambar 2.

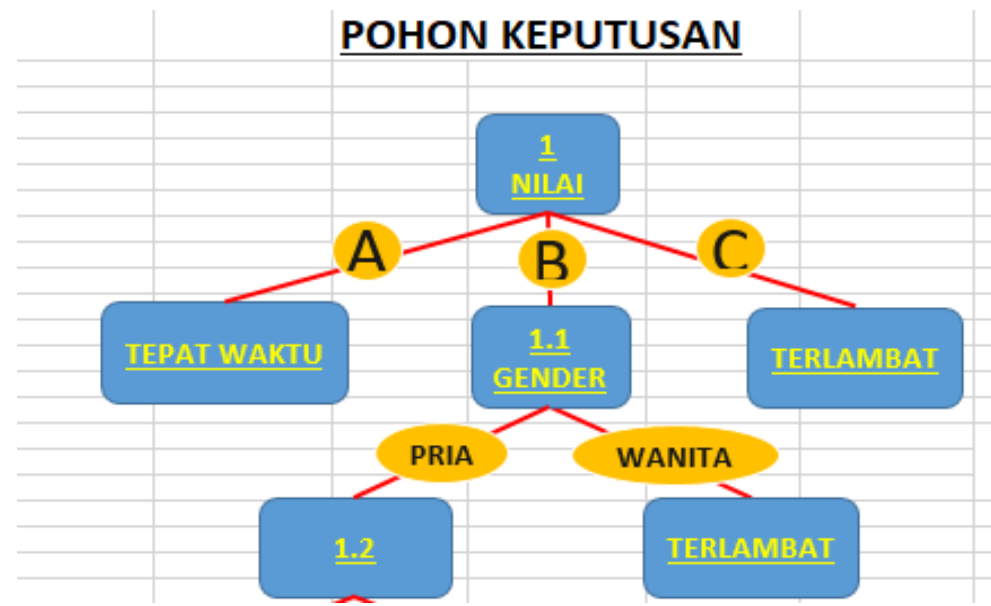

Gambar 1. Decision Tree Node 1.1

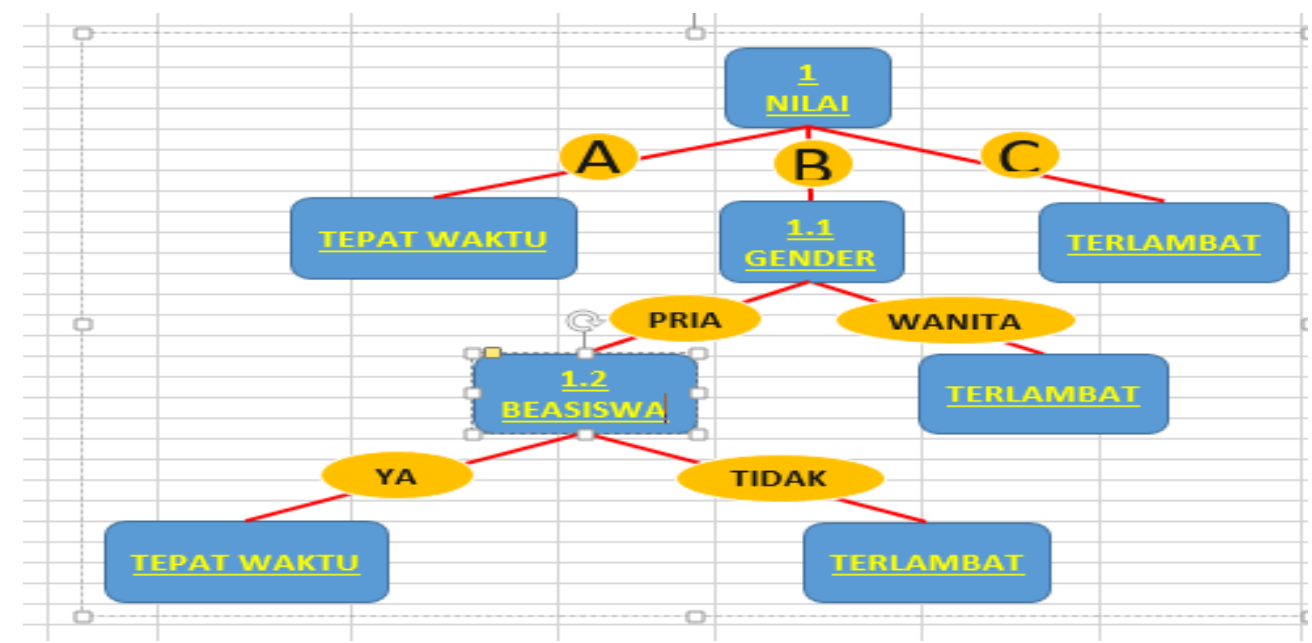

Gambar 2. Decision Tree Node 1.2 
Pada Gambar 2 ada 2 nilai atribut "Gender" yaitu "Pria" dan "Wanita" dimana didapatkan nilai "Wanita" adalah "Terlambat" dan nilai "Pria" masih belum bisa diputuskan, oleh karena itu nilai "Pria" dihitung entrophy dan gain lebih lanjut, terlihat pada Tabel 10. Dari hasil Tabel 10 dapat diketahui bahwa atribut dengan gain tertinggi adalah "Beasiswa" yaitu 0,985228. Dengan demikian "Beasiswa" dapat menjadi node cabang dari "Nilai" yang bernilai "B" dan juga "Gender" yang bernilai pria. Dari Hasil perhitungan nilai entropy dan gain pada node 1.2, maka dapat digambarkan decision tree akhir seperti terlihat pada Gambar 3. Berdasarkan Gambar 3 maka didapatkan Decision Tree akhir dapat ditarik kesimpulan bahwa IF Nilai $=\mathrm{B}$ AND Gender $=$ Pria AND Beasiswa $=$ YA THEN Tepat Waktu.

Tabel 10. Perhitungan Gain dan Entrophy pada Node 1.2

\begin{tabular}{|c|c|c|c|c|c|c|c|}
\hline Node & Atribur & Kelas & Jumlah (S) & TEPAT WAKTU (Si) & Terlarnbat (\$i) & Entrophy & Gain \\
\hline \multirow[t]{7}{*}{12} & Total & & 14 & 6 & 8 & 0,985228 & \\
\hline & Status Mahasiswa & & & & & & 0,00134 \\
\hline & & Mahasiswa & 5 & 2 & 3 & 0,970951 & \\
\hline & & Beskerja & 9 & 4 & 5 & 0,991076 & \\
\hline & Beasiswa & & & & & & 0,985228 \\
\hline & & YA & 9 & 9 & 0 & 0 & \\
\hline & & Tidak & 0 & 0 & 0 & 0 & \\
\hline
\end{tabular}

\section{Komparasi Akurasi Metode Naive Bayes dan Decision Tree}

Menghitung tingkat akurasi metode naive bayes dengan cara membandingkan data yang sudah ada dan juga prediksi yang telah dihitung. Sedangkan Menghitung tingkat akurasi metode decision tree dengan cara membandingkan data yang sudah ada dan juga prediksi yang telah dihitung. Berdasarkan perhitungan yang telah ditentukan dengan menggunakan 100 data sample mahasiswa yang diambil secara acak sebagai bahan perhitungan maka didapatkan hasil akhir yaitu perhitungan menggunakan Metode Decision Tree mendapatkan hasil dengan tingkat akurasi 55\%, dan perhitungan menggunakan Metode Naive Bayes mendapatkan tingkat akurasi sebesar 30\%. Berdasarkan perhitungan tersebut dapat diketahui bahwa perhitungan menggunakan Metode Decision Tree lebih akurat.

\section{KESIMPULAN}

Berdasarkan perhitungan yang telah ditentukan dengan menggunakan 100 data sample yang sama dari masing-masing metode sebagai bahan perhitungan maka didapatkan hasil akhir yaitu perhitungan menggunakan Metode Decision Tree mendapatkan hasil dengan tingkat akurasi 55\%, dan perhitungan menggunakan Metode Naive Bayes mendapatkan tingkat akurasi sebesar 30\%. Dari perhitungan tersebut dapat disimpulkan bahwa tingkat akurasi Metode Decision Tree lebih tinggi dibandingkan tingkat akurasi Metode Naive Bayes, maka penulis memberi saran kepada penelitia data mining selanjutnya untuk lebih menggunakan Metode Decision Tree daripada Metode Naive Bayes.

\section{REFERENSI}

[1] D. Marutho, "PERBANDINGAN METODE NAÏVE BAYES , KNN , DECISION TREE PADA LAPORAN WATER LEVEL JAKARTA,” pp. 90-97, 2019.

[2] H. Leidiyana, "Penerapan Algoritma K-Nearest Neighbor Untuk Penentuan Resiko Kredit Kepemilikan Kendaraan Bermotor,” J. Penelit. Ilmu Komputer, Syst. Embed. Log., 2013.

[3] S. Defiyanti and D. L. Crispina Pardede, "Perbandingan kinerja algoritma id3 dan c4.5 dalam klasifikasi spam-mail," ReCALL, 2008. 
[4] K. Hastuti, “Analisis komparasi algoritma klasifikasi data mining untuk prediksi mahasiswa non aktif," Semin. Nas. Teknol. Inf. Komun. Terap., 2012.

[5] P. G. S. C. Nugraha, I. W. Aribawa, I. P. O. Priyana, and G. Indrawan, "PENERAPAN METODE DECISION TREE(DATA MINING) UNTUK MEMPREDIKSI TINGKAT KELULUSAN SISWA SMPN1 KINTAMANI," Semin. Nas. Vokasi dan Teknol., 2016.

[6] D. Dicky Nofriansyah, "Penerapan Data Mining dengan Algoritma Naive Bayes Clasifier untuk Mengetahui Minat Beli Pelanggan terhadap Kartu Internet XL ( Studi Kasus di,” Saintikom, 2016.

[7] A. Fathan Hidayatullah, M. Rifqi Ma, and arif Program Studi Manajemen Informatika STMIK Jenderal Achmad Yani Yogyakarta Jl Ringroad Barat, "Penerapan Text Mining dalam Klasifikasi Judul Skripsi," Semin. Nas. Apl. Teknol. Inf. Agustus, pp. 1907-5022, 2016.

[8] Rismayanti, "Decision Tree Penentuan Masa Studi Mahasiswa Prodi Teknik Informatika ( Studi Kasus : Fakultas Teknik dan Komputer Universitas Harapan Medan )," Query, 2018.

[9] S. Wahyuningsih, "Perbandingan Metode K-Nearest Neighbor , Naïve Bayes dan Decision Tree untuk Prediksi Kelayakan Pemberian Kredit,” Konf. Nas. Sist. Inf. 2018, 2018.

[10] "PERBANDINGAN METODE NAIVE BAYES CLASSIFIER DENGAN METODE DECISION TREE (C4.5) UNTUK MENGANALISA KELANCARAN PEMBIAYAAN (Study Kasus : KSPPS / BMT AL-FADHILA,” J. Teknol. Inf. Magister Darmajaya, 2016. 